\title{
Immunohistochemical studies of leprous neuritis
}

\author{
R NILSEN, R N MSHANA, Y NEGESSE, G MENIGISTU \& \\ B KANA
}

\author{
Armauer Hansen Research Institute (AHRI) and All Africa Leprosy \& \\ Rehabilitation Training Center (ALERT), Addis Ababa, Ethiopia.
}

\begin{abstract}
Biopsies from 44 patients with a diagnostic histology of leprosy in either the nerve or the skin biopsy were used to study different aspects of leprous neuritis. Biopsy specimens from 14 out of 44 patients showed histologically a diagnostic picture of leprosy in the nerve lesions but not in the skin. Eight of 11 patients had a paucibacillary $(\mathrm{BI}=0)$ skin lesion and a multibacillary $(\mathrm{BI}>3)$ nerve lesion. The immunohistochemical studies revealed that the nerve lesions of this group had low $\mathrm{T}$ helper/suppressor ratio, low number of IL-2 receptor positive cells and low number of IL-2 containing cells, corresponding to the findings in nerve at the lepromatous part of the scale. This emphasized the importance of developing good methods for proper classification and thus appropriate treatment of the patients. The paucibacillary nerve lesions in patients with borderline tuberculoid skin lesions had higher numbers of IL-2 receptor positive cells, $\mathrm{T}$ helper lymphocytes and $\mathrm{Th} / \mathrm{Ts}$ ratios $(\mathrm{p}<0.001)$ than those from lepromatous leprosy patients. The expression of the transferrin receptor was equal. An evident number of B lymphocytes (leu14+ cells) were found in all lesions studied, showing that the humoral immune system may be more involved in the pathogenesis of the leprous lesions than previously thought. Schwann cells in all types of lesions showed a strong staining for the anti HLA-DR and HLA-DQ antigens in contrast to Schwann cells in normal nerves. Much deposites of complement factor C9 and C3 and almost no Clq were found on Schwann cells suggesting an activation of the alternative pathway of the complement system.
\end{abstract}

\section{Introduction}

Leprosy is a chronic granulomatous disease giving clinical manifestations on the skin and in peripheral nerves. The disease is caused by the essentially non-toxic mycobacterium leprae and the disease manifests itself in a spectrum from lepromatous (LL) to Tuberculoid (TT) leprosy (1). Although the skin lesions are used as the main criteria for classification (2), the peripheral nerves seem to be predilection sites for $M$. leprae $(3,4,5,6)$.

It has been reported that differences in the classifications of nerve lesions and the skin lesions may exist (6). The pathogenesis of the lesions occuring in the nerve and partly also in the skin is poorly understood. However, the host immune responses towards $M$. leprae seems to play dominant roles in determining the clinical type of the disease throughout the wide spectrum of leprosy $(7,8)$. In patients with BT leprosy, neuritis occurs early in the cause of the disease, and in vitro analyses show high lymphoproliferative responses to $M$. leprae $(1,9)$. In patients with LL leprosy nerve damage is demonstrated later in the course of the disease, and in vitro studies show decreased or lack of lymphoproliferative response to 
M. leprae (9). Thus cell mediated immunity seems to play a dominant role in the pathogenesis of leprosy lesions, yet there are some indications that humoral immune reactions may be involved in leprosy neuropathy as well $(10,11)$. The phenotypic characterization of the cellular components of the inflammatory infiltrates of the skin lesions of leprosy patients (12-18) has revealed a shift from a dominance of $\mathrm{T}$ helper lymphocytes (Th) at the tuberculoid pole to a dominance of $\mathrm{T}$ suppressor/cytotoxic lymphocytes (Ts) at the lepromatous pole. In spite of the fact that nerves are predilection sites for the disease immunohistochemical studies have not been reported.

The present report will present data from: 1. Comparative studies of the diagnostic differences between skin and nerve biopsies. 2. Studies of phenotypic characterization of the cellular infiltrates of leprous neuritis and expression of activation markers in these lesions. 3 . Studies of complement activation in lesions of leprous neuritis.

\section{Material and methods}

\section{COMPARATIVE STUDY OF NERVE AND SKIN BIOPSIES}

This study included a total of 81 patients who have had nerve and skin biopsies performed for the diagnosis of leprosy. The skin lesions were classified histologically according to the well established criteria of Ridley and Jopling $(2,19,20)$. The nerve lesions were classified as either paucibacillary leprosy with a bacterial index $(\mathrm{BI}), \mathrm{BI}<2$ or multibacillary leprosy lesions with a BI $>2$. The biopsies were fixed in FMA fixative (20), routinely processed and embedded in paraffin and stained with TRIFF stain and a modified Fite Farraco stain for acid fast bacillae (AFB) (20).

\section{STUDIES OF CELL TYPES AND CELL MARKERS IN LEPROSY LESIONS}

In these immunohistochemical studies 21 leprosy patients were included. They were all patients at ALERT hospital. In addition to the diagnostic biopsies from skin and peripheral nerves one part of the biopsies were frozen in isopentane at $-140^{\circ} \mathrm{C}$. Two normal nerves from leprosy patients and 2 from normal individuals were also included. The nerve biopsies were taken from radial cutaneous nerve $(n=20)$ and the sural nerve $(n=1)$. The biopsies were then diagnosed and classified as mentioned.

For the studies of phenotypic characterization of the cells in the lesions the patients with both nerve and skin biopsies $(n=24)$ were classified into four groups. The first group (BTN) consisted of 6 patients with a histological diagnosis of borderline tuberculoid (BT) leprosy of the skin and paucibacillary leprosy (PB) of the nerve. All except one were untreated. The second group (BBN) consisted of 4 patients with a histological diagnosis of borderline borderline leprosy (BB) of the skin. Two of them had paucibacillary nerve lesions and 2 had multibacillary ones $(\mathrm{BI}=3)$ of the nerve. The third group $(\mathrm{LLN})$ consisted of 7 untreated patients with the diagnosis of lepromatous leprosy (LL) in the the skin biopsies and multibacillary leprosy $(\mathrm{MB})$ of the nerve $(\mathrm{BI}>4)$ ). The fourth group $(\mathrm{PM})$ consisted of 5 untreated patients with a histology of a $\mathrm{BT}$ leprosy lesion of the skin $(\mathrm{BI}=0)$ and $\mathrm{MB}$ leprosy of the nerve $(\mathrm{BI}>3)$. Frozen biopsies from skin lesions from 5 untreated patients with BT leprosy and 6 patients with untreated LL leprosy were also included.

\section{STUDIES OF COMPLEMENT ACTIVATION IN NERVE LESIONS}

Two groups were studied: One group (BTN) of 6 patients having BT skin lesions and paucibacillary nerve lesions $(\mathrm{BI}=0)$, one group $(\mathrm{BBN})$ of 2 patients with $\mathrm{BB}$ skin lesions and pau- 
cibacillary nerve lesions $(\mathrm{BI}=0)$, and one group $(\mathrm{LLN})$ of 6 patients with LL lesions of the skin and multibacillary nerve lesions $(\mathrm{BI}>3)$.

For study 2 and 3 also 4 normal nerves, and for study 3 one biopsy from a skin lesion of Discoid Lupus Erythematosus were used.

\section{IMMUNOHISTOCHEMICAL METHODS}

For study 2 a triple layer immunofluorescence technique (21) were performed; in brief blocking with normal swine serum, incubation with monoclonal antibodies (Becton Dickinson, Sunnyval Ca. USA) followed by FITC labelled Rabbit anti-mouse IgG and then FITC labelled swine anti-rabbit IgG (F205 and F261, Dakopatts, Copenhagen, Denmark). The monoclonal antibodies used were: Leu-4 (pan T cells), Leu-2a (Suppressor/cytotoxic T cells (Ts)), Leu-3a+b (helper T cells (Th)), TAC (IL-2 receptor), antitransferrin receptor (TR), Leu-M5 (mature monocytes/macrophages), Leu-14 (B cells), Leu-10 (anti-HLA-DQ(DC/DS)), and anti-HLA-DR. The dilutions ranged from 1 to $5 \mu \mathrm{g} / \mathrm{ml}$ according to titration tests performed. The dilutions of the rabbit and swine antibodies were done in phosphate buffer saline (PBS) containing $50 \%$ pooled human normal serum. All other dilutions were performed in PBS.

An indirect fluorescent antibody study was employed on this material using a rabbit anti-IL-2 (Collaborative Research A/S, USA, dil. $60 \mu \mathrm{g} / \mathrm{ml}$ ) followed by FITC labelled swine antirabbit IgG (Dakopatts). In the last study of complement activation (study 3) TRITC labelled rabbit anti complement factor C9 (Behringwerke, USA) and FITC labelled rabbit anti complement factor Clq (Behringwerke, USA) and C3c (Dakopatts) were used in optimal dilution.

All sections were examined with incident light in a Leitz Orthoplan Fluorescent microscope equipped with ploemopak with filters I2, K2 and N2, and a $200 \mathrm{~W}$ mercury lamp. Countings were performed at least in 5 fields in each specimen in a square of $0.05 \mathrm{~mm}^{2}$. The countings were done without knowing the diagnosis of the slides, and control countings revealed good correlation between the countings performed on the same sections. Statistical analysis of the means were performed by t-test for independant samples. For the lesions where we had serial sections incubation for leu4, leuM5, and Leul 4 were performed and the sum was used as the total cell count in the lesion when calculating the $\%$ of the different cell types in the lesions.

\section{Results}

The studies of the 81 parallel skin and nerve biopsies showed 44 with the histological diagnosis of leprosy. Out of these 14 had a positive diagnosis of leprosy in the nerve biopsy but not in the skin. In addition it was shown that 8 out of 11 patients with multibacillary leprosy in the nerve biopsies $(\mathrm{BI}>3)$ had a paucibacillary leprosy $(\mathrm{BI}=0)$ in the skin biopsies.

\section{LYMPHOCYTE POPULATIONS AND MACROPHAGES IN NERVE LEPROSY LESIONS}

The results expressed as percentage of the sum of the cells are summarized in table 1 . The percentages of $\mathrm{T}$ cells varied only to a certain extent between the groups studied. The lower percentage of $\mathrm{T}$ cells in the LLN group compared to the BTN group were not significantly different. When analysing the total counted numbers $\left(\right.$ cells $\left./ 0.005 \mathrm{~mm}^{2}\right)$ of $\mathrm{T}$ cells in the lesions, however, a significantly lower number $(\mathrm{P}<0.05)$ of $\mathrm{T}$ cells was found in the LLN $(38 \pm 18 n=5)$ compared to the BTN group $(93 \pm 24, n=7)$. 
Table 1. Composition of the cellular infiltrates in lesions of peripheral leprosy neuropathy.

\begin{tabular}{lccccc}
\hline Diagn. & Number & $\begin{array}{c}\text { T-lymph. } \\
\%\end{array}$ & $\begin{array}{c}\text { B-lymph. } \\
\%\end{array}$ & $\begin{array}{c}\text { Macroph. } \\
\%\end{array}$ & $\begin{array}{c}\text { T H/S } \\
\text { ratio }\end{array}$ \\
\hline BTN & $(4)$ & $49 \pm 7$ & $23 \pm 10$ & $30 \pm 8$ & $1.8 \pm 0.3$ \\
BBN & $(3)$ & $42 \pm 3$ & $25 \pm 6$ & $22 \pm 9$ & $1.3 \pm 0.4$ \\
LLN & $(5)$ & $41 \pm 7$ & $22 \pm 8$ & $38 \pm 7$ & $0.5 \pm 0.1$ \\
PM & $(2)$ & $48 \pm 3$ & $18 \pm 8$ & $34 \pm 5$ & $0.6 \pm 0.2$ \\
\hline
\end{tabular}

The $\%$ of the cell types is calculated as the $\%$ of the sum of the T cells (leu $4+$ cells), B cells (leu14+ cells), macrophages (leuM5+ cells).

When analysing the data from the countings of the subtypes of T lymphocytes (number of positive cells per $0.005 \mathrm{~mm}^{2}$ ) marked differences were found. Firstly, a significantly lower $\mathrm{Th} / \mathrm{Ts}$ ratio $(\mathrm{p}<0.001)$ was found in the LLN group and the PM group compared to the BTN group. The results of the Th/Ts between the BTN and LLN group corresponded to what we found in the skin lesions $(1.7 \pm 0.6(n=5)$ vs $0.5 \pm 0.1(n=6))$. Secondly, a significantly higher $(\mathrm{p}<0.001)$ number of Th was found in the BTN group $(57 \pm 11(\mathrm{n}=6))$ compared to both the LLN $(13 \pm 6(n=9))$ as well as the PM group $(27 \pm 8(n=5))$. In the BBN group $(n=4)$ there was also a higher $(\mathrm{p}<0.05)$ number than the LLN group. The differences in the numbers of Ts cells, however, were not significant between the groups (BTN $33 \pm 12(n=6)$; LLN $28 \pm 13(n=9)$; BBN 52 $211(n=4) ; \operatorname{PM~} 38 \pm 19(n=5))$.

The inflammatory cell infiltrates in the nerves were not usually not organized in granulomas in the same manner as in the skin biopsies: in the nerves the infiltrates were more diffuse. This pattern was also reflected in the staining pattern of the T cells. In the BTN group, however, an evident peripheral segregation of the Ts cells were found in contrast to the picture in the LLN and PM groups. The Th cells were more dispersed throughout. In the LLN group the $T$ cells were found with the highest number in the perineural area while they were found more endoneurally in the BTN group. The PM group showed a distribution of T cells resembling the LLN group.

\section{MACROPHAGES:}

The macropages were found in all groups studied without any significant differences in the $\%$ of the cells in the lesion. The number of macrophages (cells $\left./ 0.005 \mathrm{~mm}^{2}\right)$ in the different groups were not significantly different from each other 8BTN $42 \pm 11(n=4)$, BBN $51 \pm 19$ $(n=3)$, LLN $37 \pm 9(n=6), P M 49 \pm 2(n=2))$. The macrophages were partly lying in groups or sheets and partly intermingled with the Schwann cells.

\section{B LYMPHOCYTES:}

The B lymphocytes were found as dense clusters and as dispersed cells in the nerve tissue (fig 1,2). there was not found any significant differences in either the $\%$ of the cells in the lesion (table 2) or the number of cells per $0.005 \mathrm{~mm}^{2}$ between the groups of patients studied

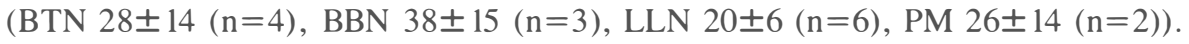

\section{TRANSFERRIN RECEPTOR (TR), IL-2 RECEPTOR (TAC) AND IL-2}

The results of the analysis of TR and TAC are summarized in table 2 . The number of TAC+ cells was significantly lower $(\mathrm{P}<0.001)$ in the LLn and PM group when compared to the BTN group. The same significant differences were found also in the skin lesions studied (18 
\pm 5.7 in BT $(n=5)$ v s $3.67 \pm 0.5(n=6)$ in $L L)$. In contrast to these results the number of TR+ cells in BTN were not different from the number found in the LLN group (Fig 3, 4). The staining pattern of the TAC positive cells appeared as small clusters in the BTN group and as very scattered cells in the LLN group (Fig 5,6)) while the TR showed more sheets of stained cells (Fig 3, 4).

Table 2. Transferrin receptor (TR) positive cells and IL-2 receptor (TAC) positive cells in lesions of peripheral leprosy neuropathies.

\begin{tabular}{lccc}
\hline Diagn. & Number & ATR + Cells $(\%)$ & TAC+ Cells $(\%)$ \\
\hline BTN & $(4)$ & $16.0 \pm 5.2$ & $14.0 \pm 1.8$ \\
BBN & $(3)$ & ND & $4.3 \pm 1.1$ \\
LLN & $(5)$ & $20.7 \pm 8.4$ & $2.7 \pm 1.3$ \\
PM & $(2)$ & $20.5 \pm 4.0$ & $3.8 \pm 2.1$ \\
\hline
\end{tabular}

The $\%$ of the cell types is calculated as the $\%$ of the sum of the T cells (leu $4+$ cells), B cells (leu14+ cells), macrophages (leuM5 + cells).

The staining for cytoplasmic IL-2 showed that the amount of cells stained in the BTN group were much higher than in the LLN and the PM group where only scattered IL- $2+$ containing cells were seen.

The expression of HLA-DR and HLA-DQ antigens was found on almost all cells of the inflammatory infiltrate. Qualitative or quantitative differences between DR and DQ expression could not be found. In addition to the staining of the inlammatory cells, Schwann cells stained strongly with the HLA-DR as well as HLA-DQ antibodies in all leprous lesions (Fig 7,9). Normal nerves in Leprosy patients or the other normal nerves studied, were devoid of this staining (Fig 8). In the skin lesions the kerationocytes overlying the BT granulomas stained strongly for DR but not for DQ while the kerationocytes above the LL lesions were all negative.

\section{COMPLEMENT ACTIVATION IN THE NERVE LESIONS}

In 4 of the 6 lesions from the BTN group slight to moderat staining for complement factor $\mathrm{C} 9$ was found on cells corresponding to Schwann cells. The deposits were found on relatively morphologically unaltered cells. The deposits were not found in the infiltrated areas except in a few small blood vessels. In the BBN group a moderate to strong staining found on Schwann cells in both lesions studied (Fig 10). In the LL group moderate to strong deposits on Schwann cells in 5 out of 6 lesions studied were found. Staining for C3 revealed moderate staining on Schwann cells in the 2 BBN lesions, 4 of the LLN lesions and not in the BTN lesions. Clq was only found in 1 of the lesions in the LLN group. Complement factor C9 but also $\mathrm{C} 3 \mathrm{c}$ and $\mathrm{Clq}$ was found in a few endoneural vessel walls. No staining in the normal nerves studied was observed.

\section{Discussion}

The comparative studies of routine biopsies (study 1) showed that there was a distinct discrepancy between the diagnosis made on a skin biopsy and that of a peripheral nerve biopsy. Both patients with normal findings in the skin biopsy and a diagnostic picture in the nervebiopsy, as well as patients exhibiting a paucibacillary leprosy in the skin biopsy and a multi- 
bacillary leprosy in the nerve biopsy were found. These findings from Ethiopia correspond with the results from Srinivasam's (6) study in south India where 19 out of 36 patients had a discrepancy between the diagnosis of the skin lesions and nerve lesions. A study of the bacteriology of several tissues of leprosy patients in India (22) showed significantly higher load of $M$. leprae in nerves than the skin from tuberculoid patients. The immunohistochemical analysis of the nerve lesions in the patients with paucibacillary leprosy of the skin and multibacillary leprosy of the nerve (study 2 , group PM) revealed that a lower Th/Ts ratio, a lower number of IL-2 receptor positive cells and fewer cells with cytoplasmic IL-2 were found compared to the paucibacillary nerve lesions in patients with BT skin lesions (study 2, BTN group). The above findings show a phenomenon comparable with dimorphic leprosy with a state of unresponsiveness to $M$. leprae more marked in the nerve than in the skin. These findings should emphasize the importance of adequate examinations before classifying patients in paucibacillary leprosy based only on the skin smear and skin biopsy and treating them accordingly.

The immunohistochemical analysis (study 2) of the nerve lesions showed approximately $50 \% \mathrm{~T}$ cells in the BT lesions and $40 \%$ in the LL lesions. These findings are in accordance with what Modlin et al. (14) found in skin lesions of leprosy. The shift in the Th/Ts ratio in nerve lesions throughout the spectrum of the disease corresponded with the observations reported by Modlin et al. $(23,24)$ and Narayanan et al. $(15,16)$ in skin lesions. The staining pattern of the $\mathrm{T}$ cell subpopulations with a peripheral segregation in the infiltrates of Ts cells in contrast to the more dispersed Th cells was more evident in the skin lesions than the nerves. The general pattern, however, corresponded to the pattern described by Modlin et al. $(12,13)$ and Narayanan et al. $(15,16)$. Our results of the analysis of the subpopulations of T cells showed that the main component leading to a switch in the T cell subpopulations was an increased number of Th cells in the BTN group compared to the LLN group. The difference in the number of Ts cells was not significant between the LLN and the BTN group. This suggest that Th cells probably play a keyrole in the determination of which type of leprosy the infection will lead to. It might then be that the relatively lack of Th cells is responsible for the non-responsiveness observed at the lepromatous part of the spectrum.

Our studies showed that it is an evident number of T cells also with in the LLN group. This might be explained by the facts that our material contained only nervebiopsies from patients having diagnosis of subpolar LL lesions in the skin biopsies. It can however also illustrate the potential of immunocompetent cells in the lesions of lepromatous leprosy.

The number of B lymphocytes was found to be as high as around $20 \%$ in all the leprosy groups studied. This contrast very much with the results found by using surface $\operatorname{IgM}$ as a marker for B cells where it was found less than $1 \% \mathrm{~B}$ cells in skin lesions (16). It is difficult, however, to evaluate the role of the B cells in the pathogenesis of the lesions of leprosy. The high number, however, should implicate an importance of the humoral immune system in the establisment of nerve lesions of leprosy.

\section{ACTIVATION MARKERS}

Antigen recognition and mitogen stimulation are associated with $\mathrm{T}$ lymphocyte proliferation and expression of cell surface activation markers (25). Recent studies of human blood T cells have demonstrated that the transferrin (TR) and IL-2 receptors (TAC) are expressed shortly (6hr) after in vitro stimulation followed later by HLA-DR expression $(25,26)$. The number of TR positive cells in the nerve lesions were much higher than the TAC positive cells corresponding to the results obtained in studies of cutaneous delayed type hypersensitivity (27). We found a significantly higher number of TAC+ (IL-2 receptor positive) cells in the BTN than the LLN or PM lesions. This corresponded to the results we obtained from the skin le- 
sions (data not shown). These results form our studies contradicted to the results reported by Modlin et al. (24) from studies of skin leprosy lesions. Even if our method might identify low as well as high avidity receptors (28) this can not explain the mentioned discrepancies. The lower number of TAC + cells and not TR + cells in the LLN compared to the BTN group, may illustrate a defect in the early $\mathrm{T}$ cell activation in the lepromatous lesions. The lack of difference, however, between LLN and BTN in the expression of TR may be explained by the fact that TR expression also are found on other cell types such as macrophages (29) and thus can mask a difference in the expression in T cells. The lack of cytoplasmic IL-2 in the LLN and the PM groups compared to the BTN group corroborate the hypothesis of defective activation. The lack of cytoplasmic IL-2 in these lesions of the nerves corresponded to the differences seen in skin lesions of leprosy (24). It has also been shown that IL-2 has the potential to induce its own receptor (30). the differences observed in the expression of the IL-2 receptor may then possibly reflect a lack of IL-2 production more than a primary defect at the receptor level.

The strong expression of HLA-DR on the inflammatory cells of the neural lesions correspond with the findings in the skin lesions as well as other studies of skin leprosy $(12,15)$. HLA-DR as well as TR expression on cells seem to have a correlation to the gamma interferon production $(29,31)$. The absence of HLA-DR on keratinocytes above LL lesions of the skin can be explained by a lack of gamma interferon production in the lesions. The HLA-DR expression on Schwann cells and endothelial cells, however, was observed in all types of leprosy nerve lesions in the present studies. These results may suggest that other factors than gamma interferon are be involved in this activation of HLA-DR, since T cells from LL patients do not produce gamma interferon upon challenge by $M$. leprae antigens (32).

The expression of the HLA class II antigens on Schwann cells raises the interesting possibility that these cells may be involved in antigen presentation to T cells. Since also keratinocytes were found to express class II molecules, these results suggest that Schwann cells and keratinocytes may play an important role in the local immunoregulation within the lesions. At present we do not know which antigens would be involved. One possibility would be that $M$. leprae antigens being presented in conjunction with the class II molecules, inducing and enhancing the local inflammatory reactions which would lead to Schwann cell damage. Another possibility may be that as a concequence of the class II expression by these cells autoantigens usually hidden for auto reactive $\mathrm{T}$ cells, may now be recognized by such $\mathrm{T}$ cells, leading to nerve destruction. In contrast to the keratinocytes, Schwann cells expressed HLA-DQ antigens. Since HLA-DQ molecules have been thought to be involved in the induction of immuno-suppression $(33,34)$ Schwann cells might be capable of activating suppressor $\mathrm{T}$ cells as well. The observation that nerves can show a more multibacillary picture than the the skin biopsy in the same patient could be compatible with this possibility.

\section{COMPLEMENT ACTIVATION}

The deposites of complement factors $\mathrm{C} 3$ and $\mathrm{C} 9$ but to a much lesser extent $\mathrm{Clq}$ in nerve lesions of multibacillary as well in paucibacillary leprous neuritis, suggest a role of complement activation in the early stage of nerve damage in leprosy. One explanation for this can be that it is an autoimmune reaction involved in the pathogenesis of leprosy $(35,36)$. The amount and intensity of the staining for $\mathrm{Clq}$ were very low compared to $\mathrm{C} 3$ and especially C9. This can be explained by an activation of the alternative pathway which corresponds with the results of complement profile studies in blood from LL patients (37). It is also shown that $M$. leprae (38) and human peripheral nerve myelin (39) can activate the alternative pathway of the complement system. The deposites of $\mathrm{C} 9$ were found mostly in areas with morphologically unaffected nerve tissue indicating that myelin expression due to des- 
troid Schwann cells is a less likely explanation. One possible explanation for such early Schwann cell damage can then be that the alternative complement activation is activated by M. leprae antigens expressed on the surface of Schwann cells.

\section{Acknowledgements}

We wish to thank Mr. Kiros Ayenew for technical assistance. Mrs. Mulunesh Negash is thanked for typing the manuscript. AHRI is financially supported by the Norwegian and Swedish Save the Children Federations. This study was supported by NIH grant No. 20198 to Wayne State University and AHRI.
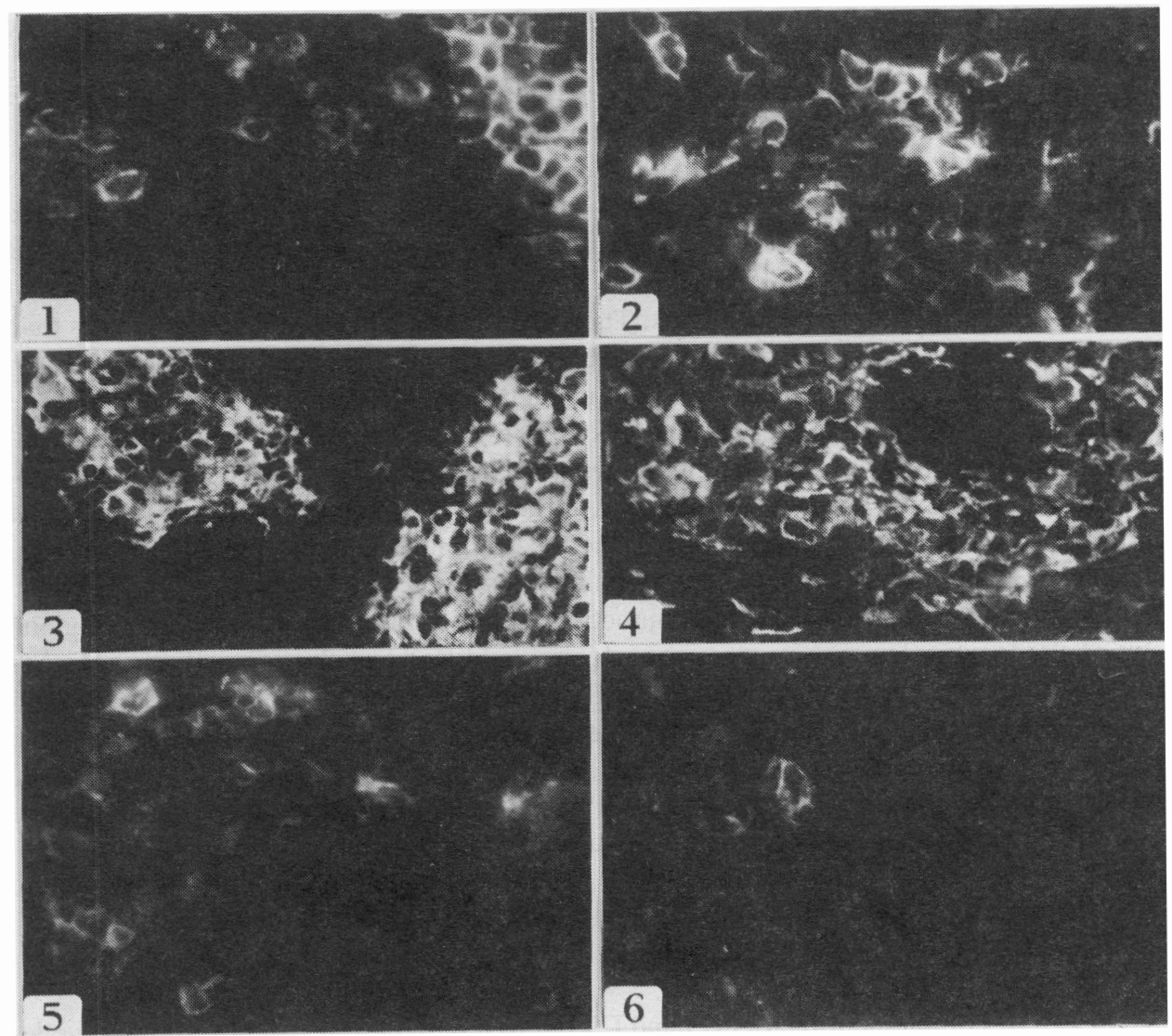

Fig 1. B lymphocytes (Leu 14) in paucibacillary nerve lesion (BTN), 400x.

Fig 2. B lymphocytes in a multibacillary nerve lesion (LLN), 400x.

Fig 3. Transferrin receptor pos. cells in a paucibacillary nerve lesion, $280 x$.

Fig 4. Transferrin receptor pos. cells in a multibacillary nerve lesion. $280 x$.

Fig 5. IL-2 receptor (TAC) pos. cells in a paucibacillary nerve lesion. 400x.

Fig 6. IL-2 receptor (TAC) pos. cell in a multibacillary nerve lesion. 400x. 

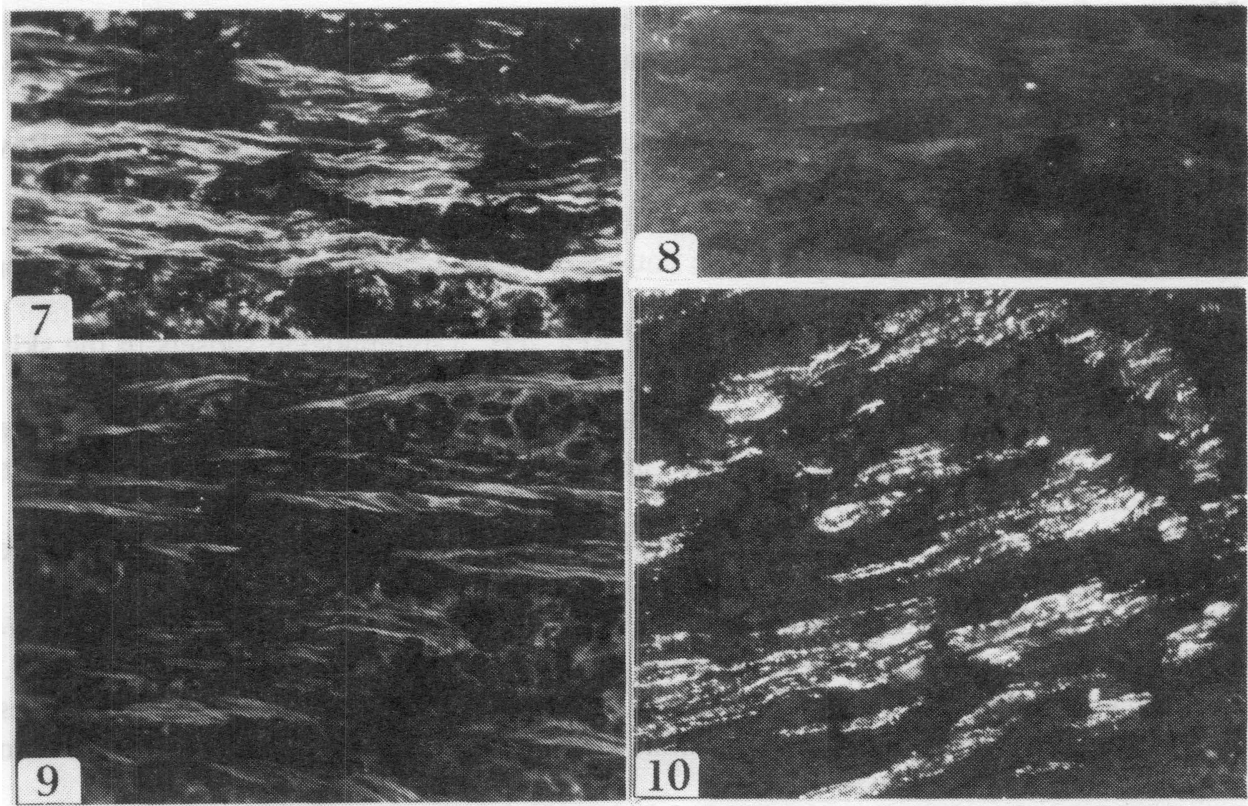

Fig 7. HLA-DR pos. Schwann cells in a paucibacillary nerve lesion. $280 x$.

Fig 8. Normal nerve in a leprosy patient showing HLA-DR negative Schwann cells. 280x.

Fig 9. HLA-DQ pos. Schwann cells in a paucibacillary nerve lesion. 280x.

Fig 10. Deposites of complement factor $C 9$ in morphologically normal Schwann cells close to an inflammatory infiltrate in a paucibacillary nerve lesion (BBN). $280 x$.

\section{References}

1 Godal, T. Immunological aspects of leprosy - present status. Prog Allergy 1978; 25: 211-242.

2 Ridley D.S., Jopling WH. Classification of leprosy according to immunity. A five group system. Int J Lepr. 1966; 34: 255-273.

3 Weddel, AGM, Pearson JMH. Leprosy. Histopathologic aspects of nerve involvement. In: Hornabrook RW, ed. Topics on Tropical neurology. Philadelphia: FA Davis Co, 1975; 17-28.

4 Boddingius, J. Mechanisms of nerve damage in leprosy. In: Humber D.P ed. Immunological aspects of leprosy, tuberculosis and leishmaniasis. Amsterdam: Excerpta Medica, 1981: 64-73.

5 Stoner, G.L. Hypothesis: Importance of the neural predilection of Mycobacterium leprae in leprosy. Lancet 1979; 994-996.

6 Srinivasam, H., Rao, KS, Iyer, C.G.S. Discrepancy in the histopathological features of leprosy lesions in the skin and periopheral nerve. Lepr India 1982; 54: 275-286.

7 Bloom, B, Mehra, V. Immunological unresponsiveness in leprosy. Immunol Reviews 1984; 80: 1-26.

8 Bloom, B, Godal, T. Selective primary health care: strategics for control of disease in the developing world. V. Leprosy. Rev Infec Dis 1983; 5: 765-780. 
9 Myrvang, B., Godal, T, Ridley, DS, et al. Immune responsiveness to Mycobacterium leprae and other mycobacterial antigens throughout the clinical and histopatological spectrum of leprosy. Clin Exp Immunol 1973; 50: 105-553.

10 Wright D, M, Hirst, R. A., Waters, MFR. Neural autoantibodies in leprosy. Lepr Rev 1975; 46: 157-169.

11 Shetty VP, Mistry NF, Antia NH. Serum demyelinating factors and adjuvant-like activity of Mycobacterium leprae: Possible causes of early nerve damage in leprosy. Lepr Rev. 1985; 56: 221-227.

12 Modlin, RL, Hofman, FM, Taylor CR and Rea, TH. T-lymphocyte subsets in the skin lesions of patients with leprosy. J Am Acad Dermatol 1983; 8: 182-189.

13 Modlin, RL, Hofman, FM, Meyer, PR, et al. In situ demonstration of T-lymphocyte subsets in granulomatous inflammation; leprosy, Rhinosleroma and sarcoidosis. Clin Exp Immunol 1983; 51: 430-438.

14 Modlin RL, Gebhard JF, Taylor CR, Rea TH. In situ characterization of T-lymphocyte subsets in the reactional states of leprosy. Clin Exp Immunol 1983; 53: 17-24.

15 Narayanan RB, Bhutani LK, Sharma AK, Nath I. T-cell subsets in leprosy lesions; in si$t u$ characterization using monoclonal antibodies. Clin Exp Immunol 1983; 51: 421-429.

16 Narayanan RB, Laal S, sharma AK, et al. Differences in predominant T-cell phenotypes and distribution pattern in reactional lesions of tuberculoid and lepromatous leprosy. Clin Exp Immunol 1984; 55: 623-628.

17 Van Voorhis WC, Kaplan G, Sarno EN et al. The cutaneous infiltration of leprosy cellular characteristics and the predominant T-cell phenotype. N Engl J Med 1982; 307: 1593-1597.

18 Wallach D, Flageul B, Bach MA, Cottenot F. The cellular contant of dermal leprous granulomas: an immunohistological approach. Int J Lepr 1984; 62: 318-326.

19 Ridley DS. Histological classification and the immunological spectrum of leprosy. Bull WHO 1974; 51: 451-465.

20 Ridley DS. Skin biopsy in leprosy. Basel Documenta Geigy 1977; 37-46.

21 Nilsen R, Johannessen AC, Skaug N, Matre R. In situ characterization of mononuclear cells in human dental periapical inflammatory lesions using monoclonal antibodies. Oral Surgery 1984; 58: 160-165.

22 Antia NH, Pandya NJ. Qualitative histology and quantitative bacteriology in various tissues of 50 leprosy patients. Lepr Rev 1976; 47: 175-183.

23 Modlin RL, Bakke AC, Vaccareo SA, et al. Tissue and blood T-lymphocyte subpopulations in erythema nodosum leprosum. Arch Dermatol 1985; 121: 216-219.

24 Modlin RL, Hofman FM, Horwitz DA, etal. In situ identification of cells in human leprosy granulomas with monoclonal antibodies to interleukin-2 and its receptor. J Immunol 1984; 132: 3085-3090.

25 Hercend T, Retz J, Schlossman \& Reinherz EL. Comparative expression of T9, 10 and Ia antigen on activated human T-cell subsets. Human Immunol 1981; 3: 247-259.

26 Cotner T, Williams JM, Christenson L et al. Simultaneously flow cytometric analysis of human T cell activation, antigen expression and DNA content. J Exp Med 1983; 157: 461-472.

27 Platt JL, Grant BW, Eddy AA, Michael AF. Immune cell populations in cutaneous delayed type hypersensitivity. J Exp Med 1983; 158: 1227-1242.

28 Robb RJ, Greene WC, Rusk CM. Low and high affinity cellular receptors for interleukin-2. Implications for the level of TAC antigen. J Exp med 1984; 160: 1126-1146. 
29 Hamilton TA, Wiel JE, Adams DO. Expression of the transferrin receptor on murine peritoneal macrophages is modulated by in vitro treatment with interferon gamma. J Immunol 1984; 89: 478-488.

30 Katzen D, Chu E, Terchorst C, et al. Mechanisms of human T cell response to mitogens: IL-2 induces IL-2 receptor expression and proliferation but no IL-2 induces IL-2 receptor expression and proliferation but no IL-2 synthesis in PHA stimulated cells. J Immunol 1985; 135: 1840-1845.

31 Rosa F, Fellous M. The effect of gamma interferon on MHC antigens. Immunology Today 1984; 5: 261-262.

32 Nogueira N, Kaplan G, Levy E, et al. Defective gamma interferon production in leprosy. Reversal with antigen and interleukin 2. J Exp Med 1983; 158: 2165-2170.

33 Corte G, Moretta A, Cosulich ME, et al. A monoclonal anti DC1 antibody selectively inhibits the generation of effector cells mediating specific cytolytic activity. J Exp Med 1982; 156: 1539-1544.

34 Kikuchi I, Sasazuki T. Immunogenic analysis of leprosy in Japan. Sixth International Congress of Immunology. Abstract 5.17. 1986; page 584.

35 Eutis-Turf EP, Benjamins JA, Lefford MJ. Characterization of the anti-neural antibodies in the sera of leprosy patients. J Neuroimmunol 1986; 10: 313-330.

36 Job CK. Pathology of peripheral nerve lesions in lepromatous leprosy, a light and electron microscopic study. Int J Lepr 1971; 39: 251-267.

37 Saha K, Sharma V, Chakrabarty AK, Sehgal NN. Breakdown product of factor B as an index of complement activation in lepromatous leprosy and its relation with bacillary load. Scand J Immunol 1983; 17: 37-43.

38 Ramanathan VD, Curtis J, Turk JL. Activation of the alternative pathway of complement by Mycobacterium and cord factors. Infect Immun 1980; 29: 30-35.

39 Kosi CL, Vanguri P, shin ML. Activation of the alternative pathway of complement by human peripheral nerve myelin. J Immunol 1985; 135: 1810-1814. 